\title{
Musculoskeletal symptoms and type A behaviour in blue collar workers
}

\author{
Bo T Flodmark, Grete Aase
}

\begin{abstract}
Objective-Type A behaviour pattern, characterised by excessive competitiveness, impatience, hostility and time urgency, has been previously investigated as a risk factor for coronary heart disease. There are few studies concerning musculoskeletal symptoms and type $A$ behaviour. Could there be a higher frequence of musculoskeletal symptoms with a more pronounced type $A$ behaviour?

Design-A cross sectional retrospective study. Standardised nordic questionnaires were used for the analysis of musculoskeletal symptoms and the Bortner questionnaire and its subscales (1) speed and (2) hard driving and competitiveness were used to assess type $A$ behaviour.
\end{abstract}

Setting-Factory based (a manufacturing industry where they make ventilating shafts).

Subjects-58 blue collar workers (51 men and seven women). Mean age was 36.9 years. Mean employment time was seven years.

Main outcome measure-Blue collar workers with musculoskeletal symptoms had a more pronounced type $A$ behaviour than those without symptoms.

Results-For shoulder symptoms during the past 12 months blue collar workers had a more pronounced type $A$ behaviour $(p<0.001)$. For symptoms during the past seven days the results were significant for the neck $(p<0.01)$, the shoulders $(p<0.01)$, and also for lower back pain $(p<0.05)$. There were no differences in age, psychosocial factors, or psychosomatic symptoms. According to the Bortner subscales, the speed subscale seems to be more important than the hard driving and competitiveness subscales.

Conclusions-Blue collar workers with a more pronounced type $A$ behaviour seem to have a higher incidence of musculoskeletal symptoms.

\footnotetext{
John Bauersgatan 4, Hälsocentralen, S-553 23 Jönköping, Sweden

B T Flodmark, G Aase
}

It has been accepted for more than 100 years that musculoskeletal problems in the neck, shoulders, arms, and hands are associated with occupations that are not necessarily heavy manual ones. In the last 10 years or so it has been recognised that the conditions are complex and hard to define within traditional musculoskeletal disease classifications and that their association with work is not simple. In the absence of the establishment of causal relation, many researchers have sought to identify associated risk factors. Independent variables studied include type of job, workstation design and posture, the use of repeated movements and forces, subject variables such as age, sex, health, and migrant state, and job design, work organisation, and psychosocial factors. ${ }^{1}$

Because ergonomic factors cannot explain all, the focus now is directed toward psychosocial factors, of which there are many aspects; one is type A behaviour. This behaviour pattern was first described by Friedman and Rosenman in $1959 .{ }^{2}$ It is characterised by excessive competitiveness, impatience, hostility, and time urgency, and has been investigated as a risk factor for coronary heart disease.

In a study of white collar workers by Swan $e a^{3} l^{3}$ no correlation was found between type $\mathrm{A}$ behaviour and musculoskeletal symptoms. According to a review by Suls and Sanders in $1988^{4}$ there were no studies of possible relations between occupational cervicobrachial disorders, lower back pain, and type A behaviour. A study by Wickström et al $^{5}$ showed that experience of back pain radiating to a leg was more common in manual workers with a competitive personality (type A behaviour) than in non-competitive workers $(p=0.03)$. No differences existed, however, in a white collar group. Results by Hägg et $\mathrm{al}^{6}$ indicated more neck and shoulder symptoms among female blue collar workers with type A personality. Type A behaviour also seemed to be a predictor of neck and shoulder disorders. Salminen et $a l^{7}$ found in their study of blue collar workers, that tenderness in the neck or shoulders on palpation was associated with type $A$ behaviour $(p<0.01)$.

The aim of this study was to investigate further the relation between type $A$ behaviour and musculoskeletal symptoms. 
Table 1 Musculoskeletal symptoms

\begin{tabular}{llll}
\hline & $\begin{array}{l}\text { Study group } \\
(n=58)\end{array}$ & $\begin{array}{l}\text { Reference } \\
\text { group } \\
(n=170)\end{array}$ & $\begin{array}{l}\text { Significance } \\
\text { of } \\
\text { difference }\end{array}$ \\
\hline $\begin{array}{l}\text { Neck: } \\
\text { Past 12 months }\end{array}$ & $29 \%$ & $26 \%$ & NS \\
Past seven days & $12 \%$ & $11 \%$ & NS \\
$\begin{array}{l}\text { Shoulders: } \\
\text { Past 12 months }\end{array}$ & $40 \%$ & $23 \%$ & p $<0.05$ \\
Past seven days & $16 \%$ & $10 \%$ & NS \\
Lower back pain: & & & \\
Past 12 months & $41 \%$ & $40 \%$ & NS \\
Past seven days & $17 \%$ & $14 \%$ & NS \\
\hline
\end{tabular}

\section{Methods}

A study by our Industrial Health Care Service was conducted during December 1989 on blue collar workers in an industry manufacturing ventilating shafts.

Standardised Nordic questionnaires for the analysis of musculoskeletal symptoms were used. ${ }^{8}$ These questionnaires have been validated. ${ }^{9} \mathrm{~A}$ questionnaire asking for symptoms like headache, tiredness, problems with stomach, eyes, nose, or skin, sleeping problems, irritation, or feeling of restlessness was used. This questionnaire is well known and widely used in Sweden and has also been validated. ${ }^{10}$ Type A behaviour was assessed by the Bortner questionnaire. The scale consists of nine steps, five being an average score in the Swedish version. ${ }^{11}$ The more evidence for type A behaviour the higher the score. The Work-APGAR questionnaire was used for psychosocial factors. ${ }^{12}$

Analysis was by Student's $t$ test for mean figures and $\chi^{2}$ test for frequencies.

\section{Results}

Fifty eight blue collar workers $(87 \%)$ (51 men and seven women) of the total 67 participated. Mean age

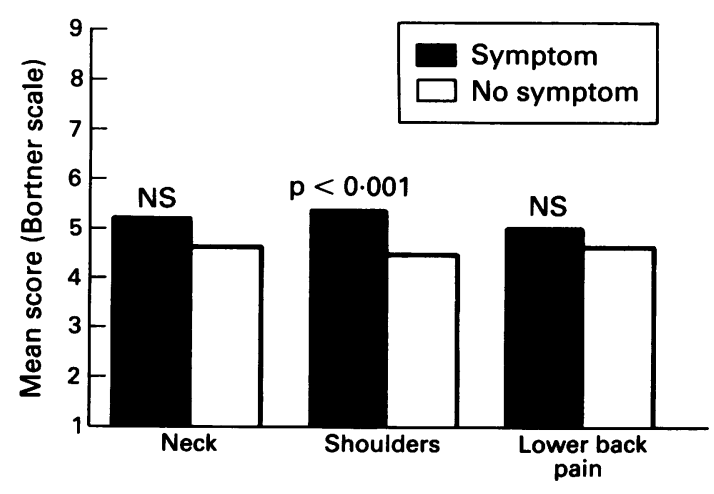

Figure 1 Musculoskeletal symptoms during the past 12 months and type A behaviour (Bortner scale) in blue collar workers.

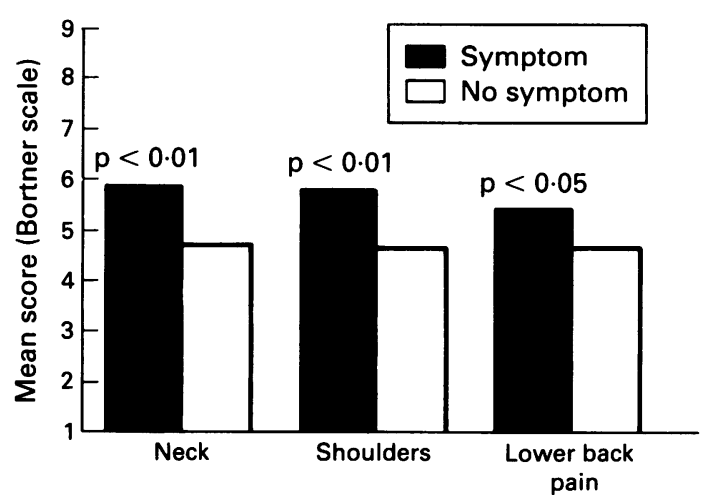

Figure 2 Musculoskeletal symptoms during the past seven days and type A behaviour (Bortner scale) in blue collar workers.

was $36.9: 31 \%$ of workers were in the age range $15-$ $29,47 \%$ in range $30-49$, and $22 \%$ in range $50-65$. They worked 40 hours a week and the mean employment time was seven years. Most of them have been working at the same tasks the past five years. Twenty eight per cent were smokers, $33 \%$ exsmokers, and $39 \%$ non-smokers.

Twenty nine per cent of the workers had had neck symptoms during the past 12 months. The figures for shoulder symptoms and lower back pain were $40 \%$ and $41 \%$ respectively. The frequencies were much lower when questions about symptoms during the past seven days were asked. To see if the frequencies of musculoskeletal symptoms were normal for blue collar workers, we found a group of 170 blue collar workers in a database in Örebro, Sweden. This consists of the same type of questionnaires answered by more than 30000 persons. ${ }^{13}$ The figures were more or less the same, except for shoulder symptoms, which were higher (table 1).

Figure 1 shows the relation between type A behaviour pattern and musculoskeletal symptoms during the past 12 months. Blue collar workers with symptoms had a more proncounced type A behaviour (higher mean scores on the Bortner scale) than those without. The mean Bortner score for the group with shoulder symptoms was significantly higher ( $p<0.001)$ compared with those without symptoms. The tendency was the same for neck symptoms and lower back pain, although the figures were not significantly different. The tendency was the same for symptoms during the past seven days. The closer the symptoms to the time questions are asked about them the higher frequencies of true answers you normally get. All these differences were significant (fig 2).

There were no differences in age or symptoms such as headache, tiredness, problems with stomach, eyes, nose, or skin, sleeping problems, irritation, or lack of concentration. The only exception was the feeling of 
Table 2 Symptoms during the past 12 months and type $A$ behaviour

\begin{tabular}{|c|c|c|c|c|}
\hline & & \multicolumn{2}{|c|}{ Past 12 months } & \multirow[b]{2}{*}{$\begin{array}{l}\text { Statistical } \\
\text { significance }\end{array}$} \\
\hline & & Symptoms & $\begin{array}{l}\text { No } \\
\text { symptoms }\end{array}$ & \\
\hline $\begin{array}{l}\text { Neck: } \\
\text { Bortner }\end{array}$ & $\begin{array}{l}\text { Global } \\
\text { HDC } \\
\text { Speed }\end{array}$ & $\begin{array}{l}5 \cdot 19 \\
4 \cdot 79 \\
5 \cdot 43\end{array}$ & $\begin{array}{l}4 \cdot 64 \\
4 \cdot 65 \\
4.79\end{array}$ & $\begin{array}{l}\text { NS } \\
\text { NS } \\
p<0.05\end{array}$ \\
\hline $\begin{array}{c}\text { Shoulders: } \\
\text { Bortner }\end{array}$ & $\begin{array}{l}\text { Global } \\
\text { HDC } \\
\text { Speed }\end{array}$ & $\begin{array}{l}5 \cdot 35 \\
5 \cdot 30 \\
5 \cdot 50\end{array}$ & $\begin{array}{l}4 \cdot 47 \\
4 \cdot 31 \\
4 \cdot 65\end{array}$ & $\begin{array}{l}\text { p }<0.001 \\
\text { p }<0.05 \\
\text { p }<0.01\end{array}$ \\
\hline $\begin{array}{l}\text { Lower back } \\
\text { Bortner }\end{array}$ & $\begin{array}{l}\text { pain: } \\
\text { Global } \\
\text { HDC^ } \\
\text { Speed }\end{array}$ & $\begin{array}{l}5 \cdot 01 \\
5 \cdot 08 \\
5 \cdot 14\end{array}$ & $\begin{array}{l}4.62 \\
4.35 \\
4.82\end{array}$ & $\begin{array}{l}\text { NS } \\
\text { NS } \\
\text { NS }\end{array}$ \\
\hline
\end{tabular}

${ }^{\star} \mathrm{HDC}=$ Hard driving and competitiveness.

restlessness for lower back pain during the past 12 months $(p<0.05)$ and during the past seven days $(p<0.01)$. There were no differences in psychosocial factors according to the Work-APGAR questionnaire to explain the results.

Recent evidence of Edwards et al ${ }^{14}$ indicates that the relation between type $A$ behaviour and coronary heart disease is dependent upon the method of measuring type $A$ behaviour. They suggest that the psychometric properties of type A behaviour measures should be carefully investigated. Rather than reflecting a single dimension, the Bortner scale contains two independent dimensions, one reflecting speed and the other hard driving and competitiveness.

Perhaps these two dimensions are of more importance than the so called true type A behaviour. The speed subscale seems more important than the harddriving and competitiveness subscale. Possibly the

Table 3 Symptoms during the past seven days and type $A$ behaviour

\begin{tabular}{|c|c|c|c|c|}
\hline & & \multicolumn{2}{|l|}{ Past 7 days } & \multirow[b]{2}{*}{$\begin{array}{l}\text { Statistical } \\
\text { significance }\end{array}$} \\
\hline & & Symptoms & $\begin{array}{l}\text { No } \\
\text { symptoms }\end{array}$ & \\
\hline $\begin{array}{l}\text { Neck: } \\
\text { Bortner }\end{array}$ & $\begin{array}{l}\text { Global } \\
\text { HDC } \\
\text { Speed }\end{array}$ & $\begin{array}{l}5 \cdot 85 \\
5 \cdot 11 \\
6 \cdot 22\end{array}$ & $\begin{array}{l}4 \cdot 68 \\
4 \cdot 64 \\
4 \cdot 82\end{array}$ & $\begin{array}{l}p<0.01 \\
\text { NS } \\
p<0.01\end{array}$ \\
\hline $\begin{array}{c}\text { Shoulders: } \\
\text { Bortner }\end{array}$ & $\begin{array}{l}\text { Global } \\
\text { HDC } \\
\text { Speed }\end{array}$ & $\begin{array}{l}5 \cdot 79 \\
5 \cdot 29 \\
5 \cdot 95\end{array}$ & $\begin{array}{l}4.62 \\
4.59 \\
4.81\end{array}$ & $\begin{array}{l}\mathrm{p}<0.01 \\
\mathrm{NS} \\
\mathrm{p}<0.01\end{array}$ \\
\hline $\begin{array}{c}\text { Lower back } \\
\text { Bortner }\end{array}$ & $\begin{array}{l}\text { pain: } \\
\text { Global } \\
\text { HDC } \\
\text { Speed }\end{array}$ & $\begin{array}{l}5 \cdot 40 \\
4 \cdot 73 \\
5 \cdot 71\end{array}$ & $\begin{array}{l}4.66 \\
4.68 \\
4.81\end{array}$ & $\begin{array}{l}\mathrm{p}<0.05 \\
\mathrm{NS} \\
\mathrm{p}<0.05\end{array}$ \\
\hline
\end{tabular}

${ }^{\star} \mathrm{HDC}=$ Hard driving and competitiveness. speed subscale is more important than the Bortner global scale (tables 2 and 3 ).

\section{Discussion}

The overall result from the questionnaires indicates a relation between type $\mathrm{A}$ behaviour and different musculoskeletal symptoms.

In the studies of Wickström et al, ${ }^{3} \mathrm{Hägg}$ et $a l,{ }^{6}$ and Salminen et $^{\mathrm{al}} \mathrm{l}^{7}$ they used their own type A scales, whereas we used the well known Bortner scale. ${ }^{15}$ Swan $e t a^{3}$ used the structured interview.

The most reliable procedure for type A diagnosis is the videobased interview (VSI) ${ }^{16}$ which evaluates both contents and expressive aspects of the pattern. Among the many questionnaires used for type A assessment, only a few including the Jenkins activity survey (JAS) ${ }^{17}$ the Bortner questionnaire, ${ }^{15} 18$ and the Framingham scale $^{19}$ have been epidemiologically validated. The questionnaires can be accepted in larger studies depending on costs. According to Kittel $^{20}$ the validity or global agreement between the structured interview and the two questionnaires (Bortner and JAS) is acceptable even for the blue collar category, although agreement of type A classification in the blue collar group was low. This could indicate that the questionnaires are less adequate for this group, which in turn might partially explain why type A was not predictive for coronary heart disease among blue collar workers in the Framingham study. ${ }^{19}$ The results by Edwards et al ${ }^{14}$ imply that the Bortner scale should not be considered as interchangeable with other measures of type $A$ behaviour, but it should instead be viewed as a measure of specific type A behaviour components. The Bortner scale should primarily be viewed as an index of speed and, to a lesser extent, competitiveness.

The notion that a behaviour pattern can function as a risk factor for a disease process was expressed by Friedman and Booth-Kewley.21 In their metaanalytic review of personality characteristics and disease, they concluded that a person's pattern of behaviour "may function like diet: imbalances can predispose one to all sorts of diseases".

One explanation of the findings could be that a competitive personality predisposes to musculoskeletal trauma in manual occupations, as people with type $A$ behaviour may be more prone to use all their strength in demanding situations than people with type B personality. ${ }^{5}$

It has been hypothesised that type A persons chronically experience greater neuroendocrine arousal..$^{22-27}$ Type A employed women in the study by Kelly and Houston ${ }^{28}$ reported more daily stress and tension. Although these are not direct measures of neuroendocrine arousal, they can be regarded as arousal related symptoms.

As with most retrospective studies, the question of which behaviour traits and response tendencies 
preceded the emergence of musculoskeletal symptoms and which followed the illness remains largely unresolved. The study by Hägg et $\mathrm{al}^{6}$ was prospective and indicated that type $A$ behaviour seemed to be a predictor of neck and shoulder disorders.

Type A persons are significantly more likely to ignore fatigue and other symptoms, more likely to work when suffering from disabilities, and less likely to take medication than type B persons, but only in challenging circumstances. ${ }^{29-31}$ When in non-challenging circumstances no A/B differences typically appear. Type A persons are thought to ignore symptoms in order to minimise their potential effect on work capacity and they tend to ignore anything that might interfere with their performance. Furthermore, illness may be labelled by type A persons as a weakness threatening their control of work situation. ${ }^{32}$ People vary in their predisposition to adopt a type A pattern and the work situation contributes to a varying degree in enhancing this behaviour. A person dedicated to a type $B$ lifestyle will often move away from the kind of social jobs and social situations that seek to force type A behaviour upon him or her. ${ }^{33}$ Type A persons possess personality traits that predispose self selection into stressful jobs. ${ }^{34}$

In challenging circumstances type A blue collar workers maybe get a higher muscle tension and hence there is a higher risk of symptoms from the muscles. It seems that one or another dimension of type A behaviour measured by the Bortner scale can correlate with musculoskeletal symptoms, but only in blue collar workers.

To conclude, the present study suggests that blue collar workers with type A behaviour (Bortner scale) have a higher incidence of neck symptoms, shoulder symptoms, and lower back pain. This is in accordance with other recently published data. ${ }^{5-7}$ The findings may indicate that type A persons drive themselves so hard that their physical abilities suffer. If prospective studies can confirm a true relation between type $A$ behaviour (or a part of it) and musculoskeletal symptoms, what conclusions can we draw? Sometimes it is easier to change the level of stimulation or demand of environments, than to change individual deepseated predispositions. Because the personality cannot easily be changed, efforts should be directed towards changing the work situation and the work organisation instead.

We thank Ms Gunilla Svensson for her assistance in the project. An abridged version of this paper was presented at the eighth international symposium, epidemiology in occupational health, Paris, France, 10-12 September, 1991.

Requests for reprints to: Dr B T Flodmark.
1 Wallace M, Buckle P. Ergonomic Aspects of neck and upper limb disorders. International reviews of Ergonomics 1987;1:173-200.

2 Friedman M, Rosenman RH. Association of specific over behavior pattern with blood and cardiovascular findings. JAMA 1959;169:1286-96.

3 Swan GE, Chesney MA, Black GW, et al. Self reported somatic symptoms in type A and type B middle-aged males. Stress Medicine 1986;2:63-8.

4 Suls J, Sanders GS. Type A behavior as a general risk factor for physical disorder. J Behav Med 1988;11:201-26.

5 Wickström G, Pentti J, Hyytiänen K, et al. Type A behaviour and back pain. Work and Stress 1989;3:203-7.

6 Hägg GM, Suurküla J, Kilbom $\AA$. Prediktorer för belastningsbesvär i skuldra/nacke. En longitudinell studie på kvinnliga montörer. Stockholm: Arbete och Hälsa 1990:10. National Institute of Occupational Health.

7 Salminen JJ, Pentti J, Wikström G. Tenderness and pain in neck and shoulders in relation to type A behaviour. Scand $J$ Rheumatol 1991;20:344-50.

8 Kuorinka I, Jonsson B, Kilbom A, et al. Standardised Nordic questionnaires for the analysis of musculoskeletal symptoms. Applied Ergonomics 1987;18:233-7.

9 Kemmlert $\mathrm{K}$, Kilbom $\AA$. Besvär i nacke/skuldra och samband med arbetssituation. En utvärdering med hjälp av frảgeformulär och arbetsplatsbesök. Stockholm: Arbete och Hälsa 1988:17. National Institute of Occupational Health.

10 Andersson $\mathrm{K}$. Utveckling och prövning av ett frảgeformulärsystem rörande arbetsmiljö och hälsotillstånd. Sweden: Rapport 2:1986. Stiftelsen för Yrkesmedicinsk och miljömedicinsk forskning och utveckling. Orebro.

11 Burell G, Sundin O Ström G, et al. Heart and lifestyle: a type A treatment program for myocardial infarction patients. Scandinavian Journal of Behavioural Therapy 1986;15:87-93.

12 Bigos SJ, Battié MC, Spengler DM, et al. A Prospective study of work perceptions and psychosocial factors affecting the report of back injury. Spine 1991;16:1-6.

13 Ydreborg B, Kraftling A. Referensdata till formulären FHV 001D, FHV 002D, FHV 003D, FHV 004D och FHV 007D. Sweden: Rapport 6:1987. Stiftelsen för Yrkesmedicinsk och miljömedicinsk forskning och utveckling i Örebro.

14 Edwards JR, Baglioni Jr AJ, Cooper CL. The psychometric properties of the Bortner Type A scale. Br J Psychol 1990; 81:315-33.

15 Bortner RW. A short rating scale as a potential measure of pattern A behaviour. Journal of Chronic Diseases 1969;22: 87-91.

16 Friedman M, Powell LH. The Diagnosis and quantitative assessment of type $A$ behavior: introduction and description of the videotaped structured interview. Integrative Psychiatry 1984;(July-August):123-9.

17 Jenkins CD, Zyzanski SJ, Rosenman RH. Progress toward validation of a computer-scored test for the type A coronaryprone behaviour pattern. Psychosom Med 1971;33:193-202.

18 Johnston DW, Shaper AG. Type A behaviour in British men: reliability and intercorrelation of two measures. Journal of Chronic Diseases 1983;36:203-7.

19 Haynes SG, Feinleib M, Kannel WB. The relationship of psychosocial factors to coronary heart disease in the Framingham study: III. Eight-year incidence of coronary heart disease. $A m J$ Epidemiol 1980;111:37-58.

20 Kittel F. Type A and other phychosocial factors in relation to coronary heart disease. In: Schmith TH, Dembroski TM, Blümchen $\mathrm{G}$, eds. Biological and psychological factors in cardiovascular disease. Berlin: Springer-Verlag, 1986:63-84.

21 Friedman HS, Booth-Kewley S. The disease prone personality: A meta-analytic view of the construct. Am Psycho 1987;42:539-55.

22 Matthews KA, Haynes SG. Reviews and commentary. Type A behavior pattern and coronary disease risk. Update and critica evaluation. Am J Epidemiol 1986;123:923-60.

23 Brackett CD, Powell LH. Psychosocial and physiological predictors of sudden cardiac death after healing of acute myocardial infarction. Am J Cardiol 1988;61:979-83.

24 Williams RB Jr, Lane JD, Kuhn CM, et al. Type A behavior and elevated physiological and neuroendocrine responses to cognitive tasks. Science 1982;218:483-5.

25 Friedman $M$. Type A behavior: A frequently misdiagnosed and rarely treated medical disorder. Am Heart J 1988;115:930-6.

26 Harbin TJ. The relationship between the type A behavior pattern and physiological responsivity: a quantitative review. Psychophysiology 1989;26:110-9.

27 Lundberg U, Granqvist M, Hansson T, et al. Psychological and 
physiological stress responses during repetitive work at an assembly line. Work and Stress 1989;3:143-53.

28 Kelly KA, Houston BK. Type A behavior in employed women: relation to work, marital, and leisure variables, social support, stress, tension, and health. J Pers Soc Psychol 1985;48: 1067-79.

29 Weidner G, Matthews KA. Reported physical symptoms elicited by unpredictable events and the type A coronaryprone behavior pattern. J Pers Soc Psychol 1978;36:1213-20.

30 Carver CS, Coleman AE, Glass DC. The coronary-prone behavior pattern and the suppression of fatigue on a treadmill test. J Pers Soc Psychol 1976;33:460-6.

31 Matthews KA, Siegel JM, Kuller LH, et al. Determinants of decisions to seek medical treatment by patients with acute myocardial infarction symptoms. $J$ Pers Soc Psychol 1983;44:1144-56.

32 Matthews KA, Brunson BI. Allocation of attention and the type A coronary-prone behaviour pattern. J Pers Soc Psychol 1979;37:2081-90.

33 Jenkins CD. Psychosocial risk factors for coronary heart disease. Acta Medica Scandanavica 1982;(suppl 660):123-36.

34 Hurrel Jr JJ. Machine-paced work and the type A behaviour pattern. Journal of Occupational Psychology 1985;58:15-25.

Accepted 20 January 1992

\section{Correspondence and editorials}

The British Journal of Industrial Medicine welcomes correspondence relating to any of the material appearing in the journal. Results from preliminary or small scale studies may also be published in the correspondence column if this seems appropriate. Letters should be not more than 500 words in length and contain a minimum of references. Table and figures should be kept to an absolute minimum. Letters are accepted on the understanding that they may be subject to editorial revision and shortening.

The journal now also publishes editorials which are normally specially commissioned. The Editor welcomes suggestions regarding suitable topics; those wishing to submit an editorial, however, should do so only after discussion with the Editor. 